\title{
CONCENTRATIONS OF K, Mg AND Na AND THEIR IONIC RELATIONS IN DACTYLIS GLOMERATA L. BIOMASS GROWN IN SOIL WITH MUSHROOM SUBSTRATE AND MINERAL FERTILISERS
}

\author{
WIŚNIEWSKA - KADŻAJAN, B. ${ }^{*}$-MALINOWSKA, E. - MISIAK, M. \\ Department of Grassland and Green Areas Creation, Siedlce University of Natural Sciences \\ and Humanities, B. Prusa 14 Street, 08-110 Siedlce, Poland \\ (phone: +48256431319) \\ *Coressponding author \\ e-mail: beata.wisniewska-kadzajan@uph.edu.pl \\ (Received $7^{\text {th }}$ Dec 2016; accepted $7^{\text {th }}$ Mar 2017)
}

\begin{abstract}
The aim of the research was to determine potassium, magnesium and sodium concentration but also the weight ratio of those macro elements in the biomass of Dactylis glomerata L. grown in a threeyear experiment. The experiment was carried out on loamy sand soil fertilized with fermented cow manure and mushroom growing substrate, the latter on its own and with mineral fertilisers applied additionally. The concentrations of those macro elements in the biomass of Dactylis glomerata showed considerable differences, depending on what fertilisers were used and from which year and cut the samples were taken. On average the concentration of potassium, magnesium and sodium in the biomass of Dactylis glomerata increased considerably if mushroom substrate and mineral fertilisers were applied. The experiment found that potassium and magnesium concentration in the grass was much higher than optimal concentration, while sodium concentration was too low.
\end{abstract}

Keywords: organic waste, fertilization, biomass of grass, chemical composition

\section{Introduction}

In Poland tillage reduces the amount of organic matter in most types of soil used for farming (Gonet, 2007). That is why such soil should be enriched with organic fertilizers and with those kinds of organic waste which are allowed to be used in agriculture. One kind of organic waste, whose amount is growing in particular in mid-eastern Poland, is mushroom substrate, left after harvesting mushrooms (Kalembasa and MajchrowskaSafaryan, 2009a, 2009b, 2006). According to Regulation of the Minister of the Environment of 27 September 2001 mushroom substrate, classified as 'other waste not mentioned here', is part of a group of waste produced. in agriculture, horticulture, hydroponic cultivation, fishery, forestry, hunting and in food processing (Regulation of the Minister of the Environment of 27 September, 2001).

To utilize mushroom substrate in agriculture its properties and chemical composition must be determined. With its nutrients easily available to plants the use of this waste in farming seems to be most appropriate as long as mushroom substrate meets the standards of environmental protection.

Chemical composition of mushroom substrate depends on production technology and the yield of mushrooms. Earlier research done by Kalembasa and Wiśniewska (2001) found that chemical composition of mushroom substrate varied considerably. According to their study potassium concentration was highly unstable, which is probably caused by the fact that this element does not occur as part of any stable organic compounds and because of that it can be easily leached from mushroom substrate during watering. 
Kalembasa and Majchrowska-Safaryan (2009a; 2009b) argue that the concentration of assimilable phosphorus and calcium is the most unstable while the concentration of organic matter and the $\mathrm{pH}$ value are the least unstable. Other publications (Uzun, 2004; Jordan et al., 2008; Maszkiewicz, 2010; Wiśniewska-Kadżajan, 2012, 2013) on the chemical composition of mushroom substrate confirm variability of its chemical composition and its chemical imbalance. Many studies have shown that composting spent mushroom substrate with other organic materials maybe a viable alternative means to reduce the environmental problems (Paredes et al., 2016; Gonzales-Marcos et al., 2014; Zhou et al., 2014; Lou et al., 2016)

The aim of the research was to determine the concentration of potassium, magnesium and sodium and the ratio of the weight of those macro elements in the biomass of Dactylis glomerata grown in soil fertilized with mushroom substrate and supplemented with nitrogen and potassium fertilizers.

\section{Materials and methods}

To do the research a three-year (2012-2014) field experiment was set up (with plots of an area of $3 \mathrm{~m}^{2}$ ) at the Experimental Station of Siedlce University of Natural Sciences and Humanities (Figure 1). The experiment was located in the Masovian Province which is located in central-eastern part of Poland.

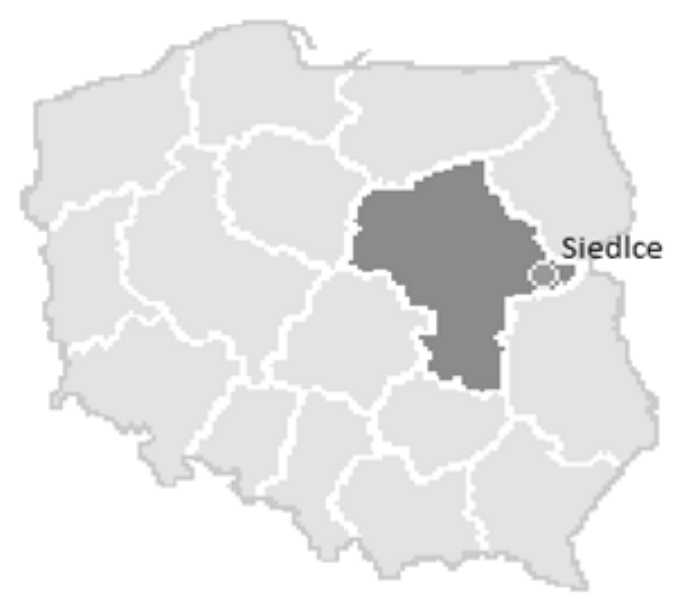

Figure 1. Place of research [http://google.pl/maps/place/Siedlce in own modification]

The research was replicated three times in a randomized design. The experiment was carried out on soil with the granulometric structure of loamy sand, belonging to the order of anthrosol soils, the group of cultural anthropogenic soils of hortic type (Marcinek, and Komisarek, 2011). The $\mathrm{pH}$ value of the soil in $0.01 \mathrm{M} \mathrm{CaCl}_{2}$ was 6.8 , carbon concentration in organic form was $13.45 \mathrm{~g} \mathrm{~kg}^{-1}$ of soil, total nitrogen was $1.32 \mathrm{~g} \mathrm{~kg}^{-1}$, while $\mathrm{C}: \mathrm{N}$ ratio was 10.2. The concentration of assimilable phosphorus was very high ( $\mathrm{P}-170 \mathrm{mg} \mathrm{kg}^{-1}$ of soil), potassium concentration was average $\left(\mathrm{K}-114.0 \mathrm{mg} \mathrm{kg}^{-1}\right.$ of soil), while assimilable magnesium concentration was high $\left(\mathrm{Mg}-84.0 \mathrm{mg} \mathrm{kg}^{-1}\right.$ of soil). 
The organic fertilisers applied were fermented cow manure (used as standard) and mushroom substrate. The concentration of potassium, magnesium and sodium in both kinds of organic substance is presented in Table 1.

Compared to manure, mushroom substrate had a lower concentration of potassium (10.8 $\left.\mathrm{g} \mathrm{kg}^{-1} \mathrm{DM}\right)$ and magnesium $\left(3.60 \mathrm{~g} \mathrm{~kg}^{-1} \mathrm{DM}\right)$, but higher concentration of sodium (1.90 $\left.\mathrm{g} \mathrm{kg}^{-1} \mathrm{DM}\right)$. The concentration of potassium in manure was $16.5 \mathrm{~g} \mathrm{~kg}^{-1} \mathrm{DM}$, magnesium $-5.30 \mathrm{~g} \mathrm{~kg}^{-1} \mathrm{DM}$ and sodium $-1.10 \mathrm{~g} \mathrm{~kg}^{-1} \mathrm{DM}$.

Table 1. Dry matter (\%) and selected macro elements $\left(\mathrm{g} \mathrm{kg}^{-1} \mathrm{DM}\right)$ concentration in organic materials used in the experiment

\begin{tabular}{cccc}
\hline \multirow{2}{*}{ Organic material } & \multicolumn{4}{c}{ The content of macro elements $\left(\mathbf{g} \cdot \mathbf{k g}^{-1} \mathbf{D M}\right)$} \\
\cline { 2 - 4 } & $\mathbf{K}$ & $\mathbf{M g}$ & $\mathbf{N a}$ \\
\hline Farmyard manure & 16.5 & 5.30 & 1.10 \\
Mushroom substrate & 10.8 & 3.60 & 1.90 \\
\hline
\end{tabular}

Both mushroom substrate and manure were applied in one dose of $20 \mathrm{tha}^{-1}$ in autumn before the grass was sown. Additionally every year the plots with mushroom substrate were fertilized with two different doses $\mathrm{N}_{1} \mathrm{~K}_{1}$ and $\mathrm{N}_{2} \mathrm{~K}_{2}$.

The doses of nitrogen were as follows: $\mathrm{N}_{1}-60$ and $\mathrm{N}_{2}-120 \mathrm{kgha}^{-1}$, in the form of $\mathrm{NH}_{4} \mathrm{NO}_{3}$, while potassium doses were $\mathrm{K}_{1}-80$ and $\mathrm{K}_{2}-160 \mathrm{~kg} \mathrm{ha}^{-1}$, in the form of $\mathrm{K}_{2} \mathrm{SO}_{4}$. Because of the high content of assimilable phosphorus in the soil, this mineral fertiliser was not applied. Yearly doses of fertilisers were divided into three equal parts. The first part was applied in spring before the growing season, the others after the second and third cut. The field was divided into the following experimental plots:

1. a control plot, without fertilisers

2. a plot with fermented manure

3. a plot with mushroom substrate

4. a plot with mushroom substrate $+\mathrm{N}_{1} \mathrm{~K}_{1}$

5. a plot with mushroom substrate $+\mathrm{N}_{2} \mathrm{~K}_{2}$.

The grass Dactylis glomerata L. of the Amila variety was used in the experiment. During each growing season three cuts were harvested. Immediately after the harvest the biomass from each plot was weighed, with $0.5 \mathrm{~kg}$ samples taken to be analyzed.

Each year potassium, magnesium and sodium concentration in dry matter was measured after the samples had been air dried and mineralized in a muffle furnace at the temperature of $450{ }^{\circ} \mathrm{C}$. The ash was put in crucibles and the hydrochloric acid was added $\left(\mathrm{HCl}: \mathrm{H}_{2} \mathrm{O}=1: 1\right)$ to dissolve carbonates and to separate silica. The chlorides formed this way were put into a $100-\mathrm{cm}^{3}$ flask, with silica removed by filtration. The AAS method with the Varian Spectra AA-20 atomic absorption spectrophotometer, together with the Merck test kit, was used to measure the concentration of potassium, magnesium and sodium.

Metrological data from between 2012 and 2014 were provided by Hydrological and Meteorological Station in Siedlce.

Sielianinow's hydrothermal index $\mathrm{K}$ was used to determine temporal and spatial variation of meteorological elements and to assess their influence on the growth of plants. It was calculated (Bac et al., 1993) dividing the sum of monthly rainfall by one- 
tenth of the total average daily temperature of the month (Table 2). The calculated values of the hydrothermal index show that there were periods of drought and severe drought during summer months.

Table 2. Sielianinow's hydrothermal index (K) by months of growing seasons $2012-2014$

\begin{tabular}{cccc}
\hline \multirow{2}{*}{ Month } & \multicolumn{3}{c}{ Years } \\
\cline { 2 - 4 } & $\mathbf{2 0 1 2}$ & $\mathbf{2 0 1 3}$ & $\mathbf{2 0 1 4}$ \\
\hline IV & 1.12 & 1.60 & 1.53 \\
V & 1.22 & 2.20 & 2.29 \\
VI & 1.56 & 1.80 & 1.20 \\
VII & 0.69 & 1.50 & 0.16 \\
VIII & 0.94 & 0.25 & 1.95 \\
IX & 0.27 & 2.70 & 0.59 \\
X & 1.32 & 1.22 & 0.13 \\
\hline
\end{tabular}

( $\mathrm{K}<0.5$ severe drought; $0.51-0.69$ drought; $0.70-0.99$ mild drought; $\mathrm{K}>1$ no drought $)$

All of the data were statistically analyzed and differences between means were assessed using analysis of variance with the Statistica software, Version 10.0 StatSoft, applied. Tukey's test was used to determine $\mathrm{LSD}_{0.05}$ for means that were significantly different (StatSoft, Inc. 2011).

\section{Results}

There was a considerable variety in the concentration of potassium in the biomass of Dactylis glomerata (Table 3). This concentration was dependent on fertilisation, cut and the year of the experiment.

The highest concentration of potassium in the biomass of Dactylis glomerata in the first and third year of the experiment (42.53 and $40.53 \mathrm{~g} \mathrm{~kg}^{-1} \mathrm{DM}$ respectively) was observed on the plots where mushroom substrate was used and where the higher dose of fertilizers was applied $\left(\mathrm{N}_{2} \mathrm{~K}_{2}\right)$, while in the second year $\left(41.20 \mathrm{~g} \mathrm{~kg}^{-1}\right)$ on the plot with the lower dose of fertilisers.

Magnesium concentration in the biomass of Dactylis glomerata (Table 4) showed considerable differences in relation to fertilization, cut and the year of the experiment. In the first and second years of the experiment, Dactylis glomerata from the plots with mushroom substrate and the higher dose of mineral fertilisers $\left(\mathrm{N}_{2} \mathrm{~K}_{2}\right)$ had the highest concentration of magnesium in the biomass: 4.62 and $4.94 \mathrm{~g} \mathrm{~kg}^{-1}$, respectively, while in the third year $\left(4.98 \mathrm{~g} \mathrm{~kg}^{-1}\right)$ in the grass from the plots with mushroom substrate and the lower dose of mineral fertilisers $\left(\mathrm{N}_{1} \mathrm{~K}_{1}\right)$. The lowest concentration of magnesium was in the first year of the experiment in the grass from the plot with manure $\left(3.07 \mathrm{~g} \mathrm{~kg}^{-1}\right)$, in the second year in the grass from the plot with mushroom substrate $\left(3.46 \mathrm{~g} \mathrm{~kg}^{-1}\right)$, while in the third year in the grass from the control plot $\left(3.45 \mathrm{~g} \mathrm{~kg}^{-1}\right)$. The three-year average of magnesium concentration in the biomass of the grass tested on the plots with mushroom substrate only was lower $\left(3.48 \mathrm{~g} \mathrm{~kg}^{-1}\right)$ than in the grass from the plot fertilized with manure, which was $\left(4.00 \mathrm{~g} \mathrm{~kg}^{-1}\right)$. 
Table 3. Potassium concentration in the biomass of Dactylis glomerata

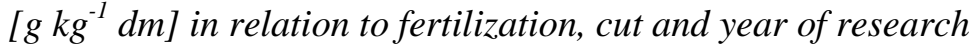

\begin{tabular}{|c|c|c|c|c|c|}
\hline \multirow{2}{*}{ Plots } & \multirow{2}{*}{ Cut } & \multicolumn{3}{|c|}{ Research year } & \multirow{2}{*}{ Average } \\
\hline & & 2012 & 2013 & 2014 & \\
\hline \multirow{3}{*}{ Control plot } & I & 30.73 & 28.80 & 26.70 & 28.74 \\
\hline & II & 29.90 & 31.71 & 23.00 & 28.20 \\
\hline & III & 29.30 & 22.50 & 22.70 & 24.83 \\
\hline \multirow{3}{*}{ Manure } & I & 33.51 & 37.60 & 31.72 & 34.26 \\
\hline & II & 33.90 & 27.80 & 29.80 & 30.50 \\
\hline & III & 37.52 & 30.20 & 30.52 & 32.73 \\
\hline \multirow{3}{*}{$\begin{array}{l}\text { Mushroom } \\
\text { substrate }\end{array}$} & $\mathrm{I}$ & 32.10 & 37.30 & 32.70 & 34.03 \\
\hline & II & 35.60 & 32.80 & 30.51 & 32.96 \\
\hline & III & 33.90 & 29.60 & 30.10 & 31.20 \\
\hline \multirow{3}{*}{$\begin{array}{c}\text { Mushroom } \\
\text { substrate } \\
+\mathbf{N}_{1} K_{1}\end{array}$} & $\mathrm{I}$ & 40.23 & 42.30 & 41.81 & 41.43 \\
\hline & II & 39.80 & 41.90 & 40.50 & 40.73 \\
\hline & III & 35.60 & 39.40 & 37.21 & 37.4 \\
\hline \multirow{3}{*}{$\begin{array}{c}\text { Mushroom } \\
\text { substrate } \\
+\mathbf{N}_{2} \mathbf{K}_{2}\end{array}$} & $\mathrm{I}$ & 43.50 & 42.90 & 42.70 & 43.03 \\
\hline & II & 42.11 & 41.50 & 40.50 & 41.36 \\
\hline & III & 42,02 & 38.50 & 38.40 & 39.63 \\
\hline \multicolumn{6}{|c|}{ Plot average } \\
\hline \multicolumn{2}{|c|}{ Control plot } & 29.96 & 27.66 & 24.13 & 27.25 \\
\hline \multicolumn{2}{|c|}{ Manure } & 34.96 & 31.86 & 30.66 & 32.50 \\
\hline \multicolumn{2}{|c|}{ Mushroom substrate } & 33.86 & 33.23 & 31.10 & 32.73 \\
\hline \multicolumn{2}{|c|}{ Mushroom substrate $+\mathrm{N}_{1} \mathrm{~K}_{1}$} & 38.53 & 41.20 & 39.83 & 39.85 \\
\hline \multicolumn{2}{|c|}{ Mushroom substrate $+\mathrm{N}_{2} \mathrm{~K}_{2}$} & 42.53 & 40.96 & 40.53 & 41.34 \\
\hline \multicolumn{2}{|c|}{ Average } & 35.97 & 34.98 & 33.25 & 34.73 \\
\hline $\begin{array}{ll}\mathrm{LSD}_{0,05} \text { for: } & \\
\text { A - fertilization } & \mathrm{A} \\
\text { B - cut } & \mathrm{A} / \mathrm{l} \\
\text { C - years } & \mathrm{C} /\end{array}$ & $\begin{array}{l}\mathrm{B}=0.27 \\
\mathrm{~B} / \mathrm{A}=\mathrm{n} . \mathrm{s} . \\
\mathrm{B} / \mathrm{C}=\mathrm{n} . \mathrm{s} .\end{array}$ & $\begin{array}{l}\mathrm{C}=0.27 \\
\mathrm{~A} / \mathrm{C}=0, \\
\mathrm{C} / \mathrm{B}=\mathrm{n} .\end{array}$ & & & \\
\hline
\end{tabular}

Table 4. The concentration of magnesium in the biomass of Dactylis glomerata [ $\left.g \mathrm{~kg}^{-1} \mathrm{DM}\right]$ in relation to fertilization, cut and year of research

\begin{tabular}{cccccc}
\hline \multirow{2}{*}{ Plots } & \multirow{2}{*}{ Cut } & \multicolumn{3}{c}{ Research year } & \multirow{2}{*}{ Average } \\
\cline { 3 - 5 } & & $\mathbf{2 0 1 2}$ & $\mathbf{2 0 1 3}$ & $\mathbf{2 0 1 4}$ & \\
\multirow{2}{*}{ Control plot } & I & 4.12 & 3.97 & 3.87 & 3.98 \\
& II & 4.25 & 3.58 & 3.54 & 3.79 \\
& III & 3.21 & 3.14 & 2.96 & 3.10 \\
\hline \multirow{2}{*}{ Manure } & I & 3.31 & 4.78 & 4.82 & 4.30 \\
& II & 3.05 & 4.64 & 4.26 & 3.98 \\
& III & 2.85 & 4.21 & 4.10 & 3.72 \\
\hline \multirow{2}{*}{ Mushroom } & I & 4.13 & 3.87 & 3.87 & 3.95 \\
substrate & II & 3.56 & 3.58 & 3.64 & 3.59 \\
& III & 2.82 & 2.89 & 2.97 & 2.89 \\
\hline \multirow{2}{*}{ Mushroom } & I & 4.75 & 5.41 & 5.47 & 5.21 \\
substrate $+\mathbf{N}_{\mathbf{1}} \mathbf{K}_{\mathbf{1}}$ & II & 4.69 & 4.65 & 5.23 & 4.85 \\
& III & 3.75 & 4.10 & 4.25 & 4.03 \\
\hline \multirow{2}{*}{ Mushroom } & I & 4.92 & 5.78 & 5.68 & 5.46 \\
substrate $+\mathbf{N}_{\mathbf{2}} \mathbf{K}_{\mathbf{2}}$ & II & 4.45 & 4.34 & 4.64 & 4.47 \\
& III & 4.50 & 4.70 & 4.29 & 4.49 \\
\hline
\end{tabular}




\begin{tabular}{|c|c|c|c|c|}
\hline \multicolumn{5}{|c|}{ Plot average } \\
\hline Control plot & 3.86 & 3.56 & 3.45 & 3.62 \\
\hline Manure & 3.07 & 4.54 & 4.39 & 4.00 \\
\hline Mushroom substrate & 3.50 & 3.46 & 3.49 & 3.48 \\
\hline Mushroom substrate $+\mathrm{N}_{1} \mathrm{~K}_{1}$ & 4.39 & 4.72 & 4.98 & 4.70 \\
\hline Mushroom substrate $+\mathrm{N}_{2} \mathrm{~K}_{2}$ & 4.62 & 4.94 & 4.87 & 4.81 \\
\hline Average & 3.89 & 4.24 & 4.23 & 4.12 \\
\hline $\begin{array}{lll}\mathrm{LSD}_{0.05} \text { for: } & & \\
\mathrm{A} \text { - fertilization } & \mathrm{A}=1.16 & \mathrm{~B}=0.46 \\
\mathrm{~B} \text { - cut } & \mathrm{A} / \mathrm{B}=\text { n.s. } & \mathrm{B} / \mathrm{A}=\text { n.s. } \\
\text { C - years } & \mathrm{C} / \mathrm{A}=\text { n.s. } & \mathrm{B} / \mathrm{C}=\text { n.s. }\end{array}$ & $\begin{array}{l}\mathrm{C}=0.76 \\
\mathrm{~A} / \mathrm{C}=\text { n.s. } \\
\mathrm{C} / \mathrm{B}=\text { n.s. }\end{array}$ & & & \\
\hline
\end{tabular}

Sodium concentration in the biomass of Dactylis glomerata (Table 5) showed considerable differences dependent on fertilization, cut and the year of the experiment. The highest concentration of sodium in the biomass of Dactylis glomerata was noted in the first year of the experiment $\left(1.49 \mathrm{~g} \mathrm{~kg}^{-1}\right)$ on the plots where mushroom substrate was applied together with the higher dose of mineral fertilizers $\left(\mathrm{N}_{2} \mathrm{~K}_{2}\right)$. In the second and third year of the experiment the highest concentration $\left(1.29\right.$ and $1.21 \mathrm{~g} \mathrm{~kg}^{-1}$, respectively) was in the grass with mushroom substrate and the lower dose of mineral fertilizers $\left(\mathrm{N}_{1} \mathrm{~K}_{1}\right)$.

Table 5. The concentration of sodium in the biomass of Dactylis glomerata $\left[\mathrm{g} \mathrm{kg^{-1 }} \mathrm{DM}\right]$ related to fertilization, cut and year of research

\begin{tabular}{|c|c|c|c|c|c|}
\hline \multirow{2}{*}{ Plots } & \multirow{2}{*}{ Cut } & \multicolumn{3}{|c|}{ Research year } & \multirow{2}{*}{ Average } \\
\hline & & 2012 & 2013 & 2014 & \\
\hline \multirow{3}{*}{ Control plot } & I & 1.12 & 0.98 & 0.87 & 0.99 \\
\hline & II & 0.94 & 0.85 & 0.76 & 0.85 \\
\hline & III & 0.93 & 0.75 & 0.75 & 0.81 \\
\hline \multirow{3}{*}{ Manure } & I & 0.90 & 1.00 & 0.99 & 0.96 \\
\hline & II & 0.86 & 0.96 & 0.92 & 0.91 \\
\hline & III & 0.85 & 0.87 & 0.78 & 0.83 \\
\hline \multirow{3}{*}{$\begin{array}{l}\text { Mushroom } \\
\text { substrate }\end{array}$} & I & 1.51 & 1.88 & 1.12 & 1.50 \\
\hline & II & 1.46 & 1.76 & 1.01 & 1.41 \\
\hline & III & 1.25 & 1.08 & 0.99 & 1.11 \\
\hline \multirow{3}{*}{$\begin{array}{c}\text { Mushroom } \\
\text { substrate }+\mathbf{N}_{1} K_{1}\end{array}$} & I & 1.52 & 1.41 & 1.30 & 1.41 \\
\hline & II & 1.20 & 1.36 & 1.24 & 1.27 \\
\hline & III & 1.34 & 1.12 & 1.08 & 1.18 \\
\hline \multirow{3}{*}{$\begin{array}{c}\text { Mushroom } \\
\text { substrate }+\mathbf{N}_{2} \mathbf{K}_{2}\end{array}$} & I & 1.54 & 1.14 & 1.25 & 1.31 \\
\hline & II & 1.48 & 1.01 & 1.10 & 1.19 \\
\hline & III & 1.46 & 0.99 & 0.94 & 1.13 \\
\hline \multicolumn{6}{|c|}{ Plot average } \\
\hline \multicolumn{2}{|c|}{ Control plot } & 0.99 & 0.86 & 0.79 & 0.88 \\
\hline \multicolumn{2}{|c|}{ Manure } & 0.87 & 0.94 & 0.89 & 0.90 \\
\hline \multicolumn{2}{|c|}{ Mushroom substrate } & 1.41 & 1.57 & 1.04 & 1.34 \\
\hline \multicolumn{2}{|c|}{ Mushroom substrate $+\mathrm{N}_{1} \mathrm{~K}_{1}$} & 1.35 & 1.29 & 1.21 & 1.28 \\
\hline \multicolumn{2}{|c|}{ Mushroom substrate $+\mathrm{N}_{2} \mathrm{~K}_{2}$} & 1.49 & 1.05 & 1.09 & 1.21 \\
\hline \multicolumn{2}{|c|}{ Average } & 1.22 & 1.14 & 1.01 & 1.12 \\
\hline $\begin{array}{ll}\text { LSD }_{0.05} \text { for: } & \\
\text { A - fertilization } & \mathrm{A}= \\
\text { B - cut } & \mathrm{A} / \mathrm{B} \\
\text { C - years } & \text { C/A }\end{array}$ & $\begin{array}{l}\mathrm{B}=0 \\
\mathrm{~B} / \mathrm{A}= \\
\mathrm{B} / \mathrm{C}=\end{array}$ & $\begin{array}{l}=0.09 \\
\mathrm{~A} / \mathrm{C}= \\
\mathrm{C} / \mathrm{B}=\end{array}$ & & & \\
\hline
\end{tabular}


The three-year average of sodium concentration in the biomass of the grass tested on plots with mushroom substrate only was higher $\left(1.34 \mathrm{~g} \mathrm{~kg}^{-1}\right)$ than in the plot fertilized with manure $\left(0.90 \mathrm{~g} \mathrm{~kg}^{-1}\right)$.

The ratio of macroelements in Dactylis glomerata grown on the plots with mushroom substrate and on plots with mushroom substrate with mineral fertilizers was much lower than optimal (Table 6). The average ratio of $\mathrm{K}: \mathrm{Na}$ in the grass from all plots ranged from 1.48 in the grass from the plot where mushroom substrate was used only to 1.29 in the grass where both mushroom substrate and the higher dose of mineral fertilisers were applied $\left(\mathrm{N}_{2} \mathrm{~K}_{2}\right)$.

Table 6. Ions ratio of the macro elements tested in the biomass of Dactylis glomerata related to fertilization, cut and year of research

\begin{tabular}{|c|c|c|c|c|}
\hline \multirow{2}{*}{ Plots } & \multicolumn{3}{|c|}{ Research year } & \multirow{2}{*}{ Average } \\
\hline & 2012 & 2013 & 2014 & \\
\hline \multicolumn{5}{|c|}{ K : Na (plot average) } \\
\hline Plot & 1.13 & 1.36 & 1.69 & 1.39 \\
\hline Manure & 1.01 & 1.38 & 1.92 & 1.44 \\
\hline Mushroom substrate & 0.92 & 1.66 & 1.86 & 1.48 \\
\hline Mushroom substrate $+\mathrm{N}_{1} \mathrm{~K}_{1}$ & 0.98 & 1.65 & 1.77 & 1.47 \\
\hline Mushroom substrate $+\mathrm{N}_{2} \mathrm{~K}_{2}$ & 1.03 & 1.30 & 1.55 & 1.29 \\
\hline Average & 1.01 & 1.47 & 1.76 & 1.41 \\
\hline \multicolumn{5}{|c|}{ K : (Ca + Mg) (Plot average) } \\
\hline Control plot & 1.13 & 1.36 & 1.69 & 1.39 \\
\hline Manure & 1.01 & 1.38 & 1.92 & 1.44 \\
\hline Mushroom substrate & 0.92 & 1.66 & 1.86 & 1.48 \\
\hline Mushroom substrate $+\mathrm{N}_{1} \mathrm{~K}_{1}$ & 0.98 & 1.65 & 1.77 & 1.47 \\
\hline Mushroom substrate $+\mathrm{N}_{2} \mathrm{~K}_{2}$ & 1.03 & 1.30 & 1.55 & 1.29 \\
\hline Average & 1.01 & 1.47 & 1.76 & 1.41 \\
\hline
\end{tabular}

\section{Discussion}

The potassium content obtained from eksperiment are confirmed by similar pot experiments on the effect of mushroom substrate on the growth of Italian ryegrass (Kalembasa and Wiśniewska, 2004, 2006, 2008a, 2008b). According to JankowskaHuflejt and Wróbel (2006, 2008) as well as Jankowska-Huflejt et al. (2006) such research on mineral substances concentration in grass is very important in breeding of ruminants because pasture grass is often the only feed for them. Jankowska-Huflejt (2009) cited by Fabijańska (1997), shortage of mineral nutrients, including potassium, in feed has a harmful effect on the growth of the young and production of mature animals, in particular on cows producing large amounts of milk. When too much potassium fertiliser is applied, plants absorb too much of this element and the absorption of other nutrients like calcium, magnesium and sodium is inhibited, which causes cation imbalance in plant and animal cells.

Falkowski et al. (2000) say that potassium concentration in meadow and pasture grass should range from 17.00 to $20.00 \mathrm{~g} \mathrm{~K} \mathrm{~kg}^{-1} \mathrm{DM}$. According to Jankowska-Huflejt et al. (2009) satisfactory concentration of potassium in hay should be $16.6 \mathrm{~g} \mathrm{~kg}^{-1} \mathrm{DM}$. 
However, Wasilewski (1997) is of an opinion that potassium concentration in grass from grasslands should be $25.0 \mathrm{~g} \mathrm{~kg}^{-1} \mathrm{DM}$ at the most.

According to the findings of the experiment it should be said that the average potassium concentration in Dactylis glomerata was very high. This high concentration of potassium in the grass was probably because of the mineral fertilisers applied. A noticeable increase of potassium concentration in the grass tested was observed on the plots with nitrogen and potassium mineral fertilisers, with both $\mathrm{N}_{1} \mathrm{~K}_{1}$ and $\mathrm{N}_{2} \mathrm{~K}_{2}$ doses. Compared to potassium concentration in the grass from the plot where only mushroom substrate was applied, nitrogen and potassium fertilization caused a potassium concentration increase of about $20 \%$.

Magnesium concentration was significantly higher in the grass from plots fertilised with mushroom substrate together with mineral nitrogen and potassium. It might have been caused by a $\mathrm{pH}$ rise after the use of the substrate. The findings of magnesium concentration in the grass tested were similar to those published by Kalembasa and Wiśniewska (2004, 2006, 2008b), who carried out an experiment using mushroom substrate to grow Italian ryegrass.

According to Falkowski et al. (2000) satisfactory magnesium concentration in fodder from meadows, pastures and hay ranges between $2.0 \mathrm{~g} \mathrm{~kg}^{-1}$ and $2.7 \mathrm{~g} \mathrm{~kg}^{-1} \mathrm{DM}$. However, Wasilewski (1997) says that magnesium concentration in pasture grass from 2.0 to $3.0 \mathrm{~g} \mathrm{~kg}^{-1} \mathrm{DM}$ is optimal. Comparing data on magnesium concentration in different feed given in the above publications and the concentration of magnesium in Dactylis glomerata presented here, it could be said that the latter concentration was above optimum.

In research by Falkowski et al. (2000), to meet requirements of ruminants sodium concentration in fodder should range from 1.5 to $2.5 \mathrm{~g} \mathrm{~kg}^{-1}$. In every year of the experiment in the grass from all plots there was a deficiency of this macro element.

Correlation between potassium and sodium is negative, i.e. a higher concentration of potassium causes a lower concentration of sodium and that is why the weight ratio ( $\mathrm{K}$ : $\mathrm{Na}$ ) between those ions is important and should be $5: 1$ (Falkowski et al. 2000). According to Jankowska-Huflejt et al. (2009) the satisfactory concentration of $\mathrm{Na}$ in feed from meadows and pastures is $1.0 \mathrm{~g} \mathrm{~kg} \mathrm{DM}$ in hay and $1.5 \mathrm{~g} \mathrm{~kg} \mathrm{DM}$ in grass.

Jankowska-Huflejt et al. (2009) cited by Wasilewski (1997) gives that the optimal K: $(\mathrm{Ca}+\mathrm{Mg})$ weight ratio in pasture grass should range between 1.9 and 2.2. On average in grass from all plots the ratio $\mathrm{K}:(\mathrm{Ca}+\mathrm{Mg})$ was lower and ranged from 1.29 in the grass from the plot with mushroom substrate and the higher dose of mineral fertilisers $\left(\mathrm{N}_{2} \mathrm{~K}_{2}\right)$ to 1.48 in the grass grown on mushroom substrate only. Feeding animals with grass in which the ratio differs from the optimal can cause metabolism disruption, which can lead to health problems and a medical condition, like tetany.

\section{Conclusions}

Potassium magnesium and sodium concentration in the biomass of Dactylis glomerata showed considerable differences, dependent on fertilisation, cut and the year of the experiment.

Each year the highest concentration of potassium and magnesium in the biomass of Dactylis glomerata was on the plots with mushroom substrate together with the higher dose of mineral fertilisers $\left(\mathrm{N}_{2} \mathrm{~K}_{2}\right)$. The highest concentration of sodium was in the grass grown in the soil with mushroom substrate and the lower dose of mineral fertilisers $\left(\mathrm{N}_{1} \mathrm{~K}_{1}\right)$. 
According to the findings, potassium and magnesium concentration in the biomass of Dactylis glomerata was significantly higher than that considered to be optimal, while there was a deficiency of sodium. This means that the weight ratio of those macro elements was not suitable.

\section{REFERENCES}

[1] Bac, S., Koźmiński, C., Rojek, M. (1993): Agrometeorology. - PWN Warszawa 32-33. (in Polish).

[2] Fabijańska, M. (1997): Animal nutrition and feedstuffs. - Warsaw, Warsaw Agricultural University p 71-73. ( in Polish).

[3] Falkowski, M., Kukułka, I., Kozłowski, S. (2000): The chemical properties of meadow plants. - Poznań: AR, p. 132. (in Polish).

[4] Gonet, S.S. (2007): Resource protection of soil organic matter. - PTSH, Wrocław, 7-29. (in Polish).

[5] Gonzales -Marcos, A., Alba Elias, F., Martinez de Pison, F. J., Alfonso-Cendon, J., Castejon-Limas, M. (2014): Composting Of spent mushroom substrate and winery sludge. - Compost Science and Utilization 23(1) : 58-65.

[6] Jankowska-Huflejt, B., Wróbel, B., Barszczewski, J. (2009) : Evaluation of nutritive value of forages from grasslands on the background of soil richness and $\mathrm{N}, \mathrm{P}, \mathrm{K}$ balances in chosen organic farms. - Journal of Research and Applications in Agricultural Engineering 54(3): 95-102.

[7] Jankowska-Huflejt, H., Wróbel, B. (2006): Analysis of the take of permanent grassland in livestock production in the selected ecological farms. - J. Res. Applic. Agric. Engng. 51 (2): 54-62. (In Polish).

[8] Jankowska-Huflejt, H., Wróbel, B. (2008): Evaluate the usefulness of feeds from grasslands for livestock production in ecological farms investigated. - J. Res. Applic. Agric. Engng. 53 (3): 103-108. (in Polish).

[9] Jankowska-Huflejt, H., Wróbel, B., Kaca, E. (2006): Utilisation and quality of fodders from grasslands in organic livestock production in Poland. - Proc. Europ. Joint Organic Congr. Organic Farm. Europ. Rural Develop., 30-31 may 2006 in Odense, Denmark, 456-457.

[10] Jordan, S.N., Mullen, G.J., Murphy, M.C. (2008): Composition variability of spent mushroom composts in Ireland. - Bioresource Technology 99: 411-418.

[11] Kalembasa, D., Majchrowska - Safaryan, A. (2006): The impact of growing mushrooms on the chemical composition of the substrate. - Advances of Agricultural Sciences Problem Issues 512: 247-254. (in Polish).

[12] Kalembasa, D., Majchrowska-Safaryan, A. (2009a): Fractions of heavy metals in waste substrates with mushrooms. - Advances of Agricultural Sciences Problem Issues 535: 195-200. (in Polish).

[13] Kalembasa, D., Majchrowska-Safaryan, A. (2009b): Fractions of heavy metals in waste substrates with mushrooms. - Environmental Protection and Natural Resources 41: 572577. (in Polish).

[14] Kalembasa, D., Wiśniewska, B. (2004): The use of spent mushroom substrate for soil remediation. - Annals of Soil Science 55 (2): 209-217. (In Polish).

[15] Kalembasa, D., Wiśniewska, B. (2006): Changes in the chemical composition of the soil and Italian ryegrass under the influence of the using of mushroom substrate. - Advances of Agricultural Sciences Problem Issues 512: 265-276. (in Polish).

[16] Kalembasa, D., Wiśniewska, B. (2008a): The content of K, Ca, Mg, S and Na in a variety of organic materials. - Advances of Agricultural Sciences Problem Issues 526: 185-190. (in Polish). 
[17] Kalembasa, D., Wiśniewska, B. (2008b): Effect of fertilization mushroom substrate on the yield and the content of selected macronutrients in Italian ryegrass. - Advances of Agricultural Sciences Problem Issues 526: 191-198. (in Polish).

[18] Kalembasa, S., Wiśniewska, B. (2001): The chemical composition of the substrate after mushrooms cultivation. - Advances of Agricultural Sciences Problem Issues 475: 295300. (In Polish).

[19] Lou, Z. M., Wang, Z. X., Zhou, X. X., Lin, Y., Xu, X. H., Kexue, H. (2016) : Compositional variation of spent mushroom substrate during cyclic utilization and its environmental impact. - Europe PMC 37(1) : 397-402.

[20] Marcinek, J., Komisarek, J. (eds.) (2011): Polish Soil Taxonomy. Collective work. Annals of Soil Science 62(3):128-134. (in Polish).

[21] Maszkiewicz, J. (2010): Spent mushroom substrate as fertilizer and fuel. - In: Mushrooms. Bulletin of mushrooms producer Publisher. Hortpress 1: 59-60. (in Polish).

[22] Paredes, C., Medina, E., Bustamante, M. A., Morel, E. (2016) : Effect of spent mushroom substrates and inorganicfertilizer on the characteristic of a calcereaus clayey-loam soil and letuce production. - Soil Use and Management 32(4) : 487-494.

[23] Regulation of the Minister of the Environment of 27 September 2001 year on catalog of waste. No 112, item. 1206.

[24] Uzun, I. (2004): Use of spent mushroom compost in sustainable fruit production. Journal of Fruit and Ornamental Plant Research 12: 157-165.

[25] Wasilewski, Z. (1997): The balance of feed and the base of summer and winter feeding of cattle. In: Production of roughage in farms specializing in integrated cattle breeding. Falenty, IMUZ, p. 83-88.

[26] Wiśniewska - Kadżajan, B. (2012): Evaluate the usefulness of the medium after the cultivation of mushrooms to fertilize the plants. - Environmental Protection and Natural Resources 54: 165-176.

[27] Wiśniewska - Kadżajan, B. (2013): Effect of fertilization permanent meadow of mushroom substrate on the content and up taking potassium and magnesium through the meadow sward. - Folia Pomeranae Universitatis Technologiae Stetinensis Agricultura Alimentaria Piscaria et Zootechnica 304(26) : 107-116.

[28] Zhou, A., Zhang, Y., Li, R., Su, X., Zhang, L. (2014) : Adsorptive removed of sulfa antibiotic from water using spent mushroom substrate, an agricultural waste. Desalination and Water Treatment 57 :388-397. 